\section{Influence of Postharvest Storage Temperature and Duration on Quality of Baby Spinach}

\author{
Ambani R. Mudau ${ }^{1}$, Mpumelelo M. Nkomo ${ }^{1}$, Puffy Soundy ${ }^{2}$, \\ Hintsa T. Araya ${ }^{3}$, Wonder Ngezimana ${ }^{4}$, and Fhatuwani N. Mudau ${ }^{1,5}$
}

Additional index words. Spinacia olevacea, storage time, shelf life

Summary. Spinach (Spinacia olevacea) is a member of the Amaranthaceae family. Baby spinach leaves have a very high respiration rate, thus postharvest quality is affected mostly by tissue decay and the development of off-odors. Thus, this study was conducted to investigate the influence of storage temperature and time on the postharvest quality of baby spinach. Baby spinach leaves were harvested $\mathbf{3 6}$ days after planting and subsequently stored at 4 and $22^{\circ} \mathrm{C}$ for $0,2,4,6,8,10$, or 12 days. Thereafter, the leaves were incubated for 72 hours at $40{ }^{\circ} \mathrm{C}$ to dry. Minerals, trace elements, total phenols, total carotenoids, flavonoids, and antioxidant activities were measured. Concentration of magnesium $(\mathrm{Mg})$, zinc $(\mathrm{Zn})$, and iron $(\mathrm{Fe})$ were declined after 8 days of storage at $4{ }^{\circ} \mathrm{C}$, while at $22^{\circ} \mathrm{C}$ they declined after 2 days of storage. $\mathrm{Mg}, \mathrm{Zn}$, and Fe revealed a similar trend with significantly higher carotenoids found up to 6 days in storage at $4^{\circ} \mathrm{C}$, while at $22^{\circ} \mathrm{C}$ the carotenoid levels declined after only 2 days. Total phenolic compounds gradually decreased in samples stored at $4{ }^{\circ} \mathrm{C}$. However, samples stored at $22{ }^{\circ} \mathrm{C}$ showed a rapid decrease after 4 days. Both total antioxidant activities and vitamin $\mathrm{C}$ content showed a similar trend, with the content remaining constant at $4{ }^{\circ} \mathrm{C}$ and decreasing after 6 days, whereas the total antioxidant activities and vitamin $\mathrm{C}$ for leaves stored at $22{ }^{\circ} \mathrm{C}$ decreased immediately after 2 days. Results demonstrated that quality of baby spinach deteriorates as storage time and temperature increase.

S pinach is a member of the Amaranthaceae family, although it previously fell under the Chenopodiaceae or goosefoot family (Maughan et al., 2004). It is generally used as a vegetable and also for medicinal purposes. Spinach harvested after a shorter growth period ranging between 35 and $45 \mathrm{~d}$ than normal is known as baby spinach (Bergquist et al., 2005). In the study conducted by Muller (1997), spinach was among the vegetables that were reported as rich in carotenoids (over $10 \mathrm{mg} / 100 \mathrm{~g}$ edible portion). Baby spinach is considered to have a high nutritional value, being a rich source of vitamins $\mathrm{C}, \mathrm{E}$,

This work was financially supported by the Gauteng Department of Agriculture and Rural Development (GDARD) administered by University of South Africa (UNISA): GUN number 359000

${ }^{1}$ Department of Agriculture and Animal Health, College of Agriculture and Environmental Sciences, University of South Africa, Private Bag X6, Florida, Johannesburg, 1710, South Africa

${ }^{2}$ Department of Crop Sciences, Tshwane University of Technology, Private Bag X680, Pretoria 0001, South Africa

${ }^{3}$ Agriculture Research Council, Vegetable and Ornamental Plant Institute, Private Bag X293, Pretoria 0001, South Africa

${ }^{4}$ University of Zimbabwe, Marondera College of Agricultural Science and Technology, P.O. Box 35, Marondera, Zimbabwe

${ }^{5}$ Corresponding author. E-mail: mudaufn@unisa.ac.za. and $\mathrm{K}$; carotenoids $\beta$-carotene and lutein; $\mathrm{Mg}$; and several antioxidants such as flavonoids (Bergquist et al., 2006; Bottino et al., 2009). Bergquist et al. $(2005)$ reported that $\approx 12$ main flavonoids have been identified in spinach. However, spinach can also possess high levels of nitrates and oxalate, which can be harmful to human health (Koh et al., 2012; Muramoto, 1999).

The postharvest shelf life of fruit and vegetables has been traditionally known and determined by means of visual appearance, including freshness, color, absenteeism of decay, and texture (Ayala-Zavala et al., 2004).
Storage conditions influence the phytochemical content of fruit and vegetables. Storage time and temperature are some of the most important factors, which have a significant impact in determining shelf life and quality of fruit and vegetable produce (Kader and Rolle, 2004). These factors may indeed lead to degradation of the nutritional quality of the produce.

It is very important to have sufficient shelf life of produce coupled with good nutritional quality for its intended consumers (Ahvenainen, 1996). Thus, it is of great importance to establish the appropriate storage time and temperature to maintain and enhance the quality of vegetables (Moretti, 2007). It has been recommended that the fresh-cut baby spinach leaves should be kept at $0{ }^{\circ} \mathrm{C}$ (Izumi et al., 1997); however, they are oftentimes stored at higher temperatures (Hulshof et al., 1997) and these often compromise quality since it has short shelf life. Spinach is a leafy vegetable that is commonly consumed fresh or as part of frozen products (Koh et al., 2012). Baby spinach is normally consumed when cooked; however, fresh leaves can also be used in salad. Since it is a yearround vegetable in most production countries, where the climatic conditions are marginally high it is critical important that the storage duration and temperature condition be established with the aim of not losing quality. Hence, the data that describe the influence of storage and temperature is in most vegetables are inconsistent. Thus, the aim of this study was to determine the effect of postharvest storage temperature and duration on quality of baby spinach in South Africa.

\begin{tabular}{llll}
\hline $\begin{array}{l}\text { Units } \\
\begin{array}{l}\text { To convert U.S. to SI, } \\
\text { multiply by }\end{array}\end{array}$ & U.S. unit & SI unit & $\begin{array}{l}\text { To convert SI to U.S., } \\
\text { multiply by }\end{array}$ \\
\hline 10 & $\%$ & $\mathrm{mg} \cdot \mathrm{g}^{-1}$ & 0.1 \\
29,574 & $\mathrm{fl} \mathrm{oz}$ & $\mu \mathrm{L}$ & $3.3814 \times 10^{-5}$ \\
29.5735 & $\mathrm{fl} \mathrm{oz}$ & $\mathrm{mL}$ & 0.0338 \\
3.7854 & gal & $\mathrm{L}$ & 0.2642 \\
25.4 & inch(es) & $\mathrm{mm}$ & 0.0394 \\
645.1600 & inch ${ }^{2}$ & $\mathrm{~mm}$ & 0.0016 \\
1 & micron $(\mathrm{s})$ & $\mu \mathrm{m}^{2}$ & 1 \\
1 & $\mathrm{mmho} / \mathrm{cm}$ & $\mathrm{dS} \cdot \mathrm{m}^{-1}$ & 1 \\
28.3495 & $\mathrm{oz}$ & $\mathrm{g}$ & 0.0353 \\
28,350 & $\mathrm{oz}$ & $\mathrm{mg}$ & $3.5274 \times 10^{-5}$ \\
0.7489 & $\mathrm{oz} / \mathrm{gal}$ & $\mathrm{g} / 100 \mathrm{~mL}$ & 1.3353 \\
1 & $\mathrm{ppm}$ & $\mathrm{mg} \cdot \mathrm{kg}^{-1}$ & 1 \\
1 & $\mathrm{ppm}$ & $\mathrm{mg} \cdot \mathrm{L}^{-1}$ & 1 \\
$\left({ }^{\circ} \mathrm{F}-32\right) \div 1.8$ & ${ }^{\circ} \mathrm{F}$ & ${ }^{\circ} \mathrm{C}$ & $\left({ }^{\circ} \mathrm{C} \times 1.8\right)+32$
\end{tabular}




\section{Materials and methods}

Plant materials and storage CONDITIONS. 'Ohio' baby spinach (Hygrotech, Pretoria, South Africa) were grown from seed in a glasshouse with temperature controlled using a pad and fan system. Plants were fertilized with a balanced nutrient solution, which contained all nutrients as described by Nemadodzi (2015). The initial soil chemical analyses were determined using a procedure described by Hanlon et al. (1994). The electrical conductivity was $0.9 \mathrm{dS} \cdot \mathrm{m}^{-1}$, and $\mathrm{pH}$ was 4.7 . The soil contained $1.2 \mathrm{mg} \cdot \mathrm{kg}^{-1}$ nitratenitrogen $\left(\mathrm{NO}_{3}-\mathrm{N}\right), \quad 0.1 \mathrm{mg} \cdot \mathrm{kg}^{-1}$ phosphorus, $1.3 \mathrm{mg} \cdot \mathrm{kg}^{-1}$ potassium (K), $0.01 \mathrm{mg} \cdot \mathrm{kg}^{-1} \mathrm{Mg}$, and 0.02 $\mathrm{mg} \cdot \mathrm{kg}^{-1} \mathrm{Fe}$. After $36 \mathrm{~d}$, all plants were harvested with scissors by simply cutting at the stem. In addition, each plant had about eight leaves and the average leaf size was 4 inches. Leaf samples were washed using running water, dried, and packed in perforated $150-\mathrm{mm}^{2}$ plastic trays. The baby spinach trays were further stored at 4 or $22{ }^{\circ} \mathrm{C}$ for $0,2,4,6,8$, or $12 \mathrm{~d}$ and the samples were freeze-dried. These temperatures were selected because $4{ }^{\circ} \mathrm{C}$ is the standard temperature used in commercial retail stores in Johannesburg, Gauteng Province, South Africa, and farmers around Gauteng Province often hold baby spinach around $22^{\circ} \mathrm{C}$. Treatments were replicated three times. Each sample was weighed and marked to estimate weight loss during storage. The full experiment was repeated three times.

Weight Loss. Weight loss was determined by weighing all samples with a balance $[ \pm 0.001 \mathrm{~g}$ (model MK500C; Denver Instrument, Bohemia, $\mathrm{NY}$ )] at the beginning and end of each storage period. The difference between the two values was considered to be the weight loss.

Mineral AND trace Elements. All mineral and trace elements were analyzed using a method described by Van der Walt et al. (2009). A $100 \mathrm{mg}$ freeze-dried sample was accurately weighed and heated in $1 \mathrm{~mL}$ of nitric acid $(70 \%)$ until clarity was achieved. After cooling, $3 \mathrm{~mL}$ of water was added and heating resumed for a further $10 \mathrm{~min}$. Finally, the solution was cooled and deionized water was added until a volume of $10 \mathrm{~mL}$ was attained. The mineral concentrations of each sample were determined using an inductively coupled argon plasma mass spectrometer (7500C ICP-MS; Agilent Technologies, Santa Clara, CA). Calibrations were performed using external standards prepared from a 1000-ppm single stock solution made up with $2 \%$ nitric acid. The external calibrations were run in the same analytical sequence as the samples.

DETERMination OF TOTAL PHENOLS. Duplicates of $2 \mathrm{~g}$ of spinach leaves were extracted using $40 \mathrm{~mL}$ of methanol. Twenty milliliters of methanol were added to $2 \mathrm{~g}$ of sample in centrifuge tubes and the sample was vortexed every $10 \mathrm{~min}$ for $2 \mathrm{~h}$ to improve extraction efficiency. Samples were centrifuged at $959 g_{n}$ for $10 \mathrm{~min}$ at $25^{\circ} \mathrm{C}$ and then decanted. Each sample residue was rinsed once with $20 \mathrm{~mL}$ of methanol, vortexed for 5 min, centrifuged as above, and decanted. Two supernatants were combined and used for analysis. The Folin-Ciocalteau method (Singleton and Rossi, 1965), modified by Waterman and Mole (1994) was used to determine total phenols.

Briefly, a sample methanolic extract $(0.5 \mathrm{~mL})$ was added to a $50-\mathrm{mL}$ volumetric flask containing distilled water and mixed. Folin-Ciocalteau phenol reagent $(2.5 \mathrm{~mL})$ was then added and mixed, followed by $7.5 \mathrm{~mL}$ of sodium carbonate solution $(20 \mathrm{~g} / 100 \mathrm{~mL})$ within 1 to $8 \mathrm{~min}$ after addition of the Folin-Ciocalteau phenol reagent (Sigma-Aldrich, Johannesburg, South Africa). The contents were mixed and the flask made up to volume with distilled water and thoroughly mixed. Absorbance of the reactants was read after $2 \mathrm{~h}$ at $760 \mathrm{~nm}$ using ultravioletvisible spectrophotometer $\left(\right.$ Genesys $^{\mathrm{TM}}$ 20; Cecil Instruments, Cambridge, UK). Catechin was used as standard to prepare a standard curve and results were expressed as milligrams catechin equivalents (CE) per 100 mg of samples on dry weight (DW) basis.

CarotenoIDs analysis. The samples for carotenoids were prepared similarly to that of total phenols preparation and subsequently analyzed using reverse-phased high-performance liquid chromatography (Shimadzu Scientific Instruments, Columbia, MD) as described by Kidmose et al. (2001), but with slight modifications. Mobile phase eluents consisted of A ( $80 \%$ methanol $/ 20 \%$ water) and B
(100\% ethyl acetate). The total run time was $34 \mathrm{~min}$ at a flow rate of $1.2 \mathrm{~mL} \cdot \mathrm{min}^{-1}$. The injection volume was $20 \mu \mathrm{L}$ for the analysis. The column used was a Nucleosil $5 \mathrm{Cl} 8$ $\left(250 \times 4.6 \mathrm{~mm}, 5 \mu \mathrm{m}\right.$; Phenomenex ${ }^{\circledR}$, Torrance, CA), with a security guard column (C18 ODS, $4 \times 3.0 \mathrm{~mm}$; Phenomenex $\left.{ }^{\circledR}\right)$. The carotenoid concentration was quantified using an external $\beta$-carotene standard (Sigma-Aldrich). The absorbance was measured at 445 nm using a diode array detector (Waters $^{\circledR}$, Milford, MA). Carotenoids were identified by a comparison of chromatographic retention times and spectral characteristics with those reported in the literature (Bergquist et al., 2007; Kidmose et al., 2001).

EVALUATION OF TOTAL FLAVONOID CONTENT. The total flavonoids were measured using a modified calorimetric method described by Yoo et al. (2008). Briefly, $1 \mathrm{~mL}$ of the extracts or standard solutions of catechin was added to a $10-\mathrm{mL}$ volumetric flask. Distilled water was added to make a volume of $5 \mathrm{~mL}$. At zero time, $0.3 \mathrm{~mL}$ of $5 \%(\mathrm{w} / \mathrm{v})$ sodium nitrite was added to the flask. After $5 \mathrm{~min}$, $0.6 \mathrm{~mL}$ of $10 \%(\mathrm{w} / \mathrm{v})$ aluminium chloride was added and, then $6 \mathrm{~min}$ later, $2 \mathrm{~mL}$ of $1 \mathrm{M}$ sodium hydroxide $(\mathrm{NaOH})$ were also added to the mixture, followed by the addition of $2.1 \mathrm{~mL}$ distilled water. The absorbance was measured against the blank at $510 \mathrm{~nm}$ after $15 \mathrm{~min}$. The standard curve was prepared using different concentrations of catechin. The flavonoid content was expressed as milligrams CE per $100 \mathrm{~g} \mathrm{DW}$.

DETERMination OF ANTIOXIDANT ACTIVITY. Antioxidant activity (by free radical scavenging) of the extracts was determined using Trolox equivalent antioxidant capacity assay as described by Awika and Rooney (2004). Briefly, 2, 2'-azino-bis (3ethylbenzothiazoline-6-sulfonic acid) (ABTS+) was produced by mixing equal volumes of $8 \mathrm{~mm}$ ABTS with $3 \mathrm{~mm}$ K persulfates. These were prepared in distilled water and allowed to react in the dark for $12 \mathrm{~h}$ at room temperature before use. The ABTS+ solution was diluted with a phosphate buffer solution $(\mathrm{pH}=7.4)$ mixed with $0.2 \mathrm{M}$ sodium acid pyrophosphate and $150 \mathrm{~mm}$ sodium chloride in $1 \mathrm{~L}$ of distilled water, with $\mathrm{pH}$ adjustment using $\mathrm{NaOH}$ when necessary. A freshly prepared solution was used for each analysis. The 
ABTS+ solution $(2900 \mu \mathrm{L})$ was added to the methanol extracts of the baby spinach leaves $(100 \mu \mathrm{L})$ of Trolox in a test tube and mixed. Absorbency readings (at $734 \mathrm{~nm}$ ) were taken after $30 \mathrm{~min}$ (for the samples) and $15 \mathrm{~min}$ (for the standard) of the initial mixing of the samples and standard, respectively. The results were expressed as micrograms Trolox equivalents per gram of sample on DW basis.

Table 1. Percentage cumulative weight loss of baby spinach stored at two different temperatures [ 4 and $22{ }^{\circ} \mathrm{C}\left(39.2\right.$ and $\left.\left.71.6^{\circ} \mathrm{F}\right)\right]$ for different storage duration $(2,4,6$, 8,10 , and $12 \mathrm{~d}$ ).

\begin{tabular}{lcr}
\hline \multirow{2}{*}{$\begin{array}{l}\text { Storage } \\
\text { duration (d) }\end{array}$} & \multicolumn{2}{c}{ Wt loss (\%) } \\
\cline { 2 - 3 } & $\mathbf{4}^{\circ} \mathrm{C}$ & $\mathbf{2 2}{ }^{\circ} \mathrm{C}$ \\
\hline 0 & $0.00 \mathrm{a}^{\mathrm{z}}$ & $0.00 \mathrm{a}$ \\
2 & $1.19 \mathrm{~b}$ & $8.11 \mathrm{a}$ \\
4 & $1.77 \mathrm{~b}$ & $12.01 \mathrm{a}$ \\
6 & $3.94 \mathrm{~b}$ & $20.03 \mathrm{a}$ \\
8 & $6.92 \mathrm{~b}$ & $25.88 \mathrm{a}$ \\
10 & $8.61 \mathrm{~b}$ & $22.51 \mathrm{a}$ \\
12 & $15.00 \mathrm{~b}$ & $29.03 \mathrm{a}$ \\
\hline${ }^{2}$ Means in rows followed by different letter are significantly
\end{tabular}

Statistical analysis. Three experiments were conducted three times and the interactions between experiments were not significantly different $(P \leq 0.05)$. Therefore, the data were pooled $(\mathrm{n}=126)$ and subjected to analysis of variance using PROC GLM of SAS (version 9.2; SAS Institute, Cary, NC). Mean comparisons were performed using Duncan's multiple range test procedure.

\section{Results}

The combined data for the four separate experiments (seasons) were presented because the data for the separate experiments did not significantly vary in all parameters analyzed. Results from this study showed that weight loss gradually increased with increase in storage temperature irrespective of the days of storage (Table 1). No significant interactions between time and storage temperature were observed during the study (Table 1).

Results exhibited a progressive deterioration in baby spinach quality with storage time progression and temperature increase. Concentration of $\mathrm{Mg}, \mathrm{Zn}$, and $\mathrm{Fe}$ declined after $8 \mathrm{~d}$ of storage at $4{ }^{\circ} \mathrm{C}$, while at $22^{\circ} \mathrm{C}$ they declined after $2 \mathrm{~d}$ of storage as shown in Fig. 1A-C.

Two parameters (i.e., carotenoid and total phenols) resembled similar trends since the significantly higher carotenoids were found up to $6 \mathrm{~d}$ in storage time at $4{ }^{\circ} \mathrm{C}$, while at $22{ }^{\circ} \mathrm{C}$ the level of carotenoid declined after only $2 \mathrm{~d}$ as shown in Fig. 2A. Total phenolic compounds decreased gradually in samples stored at $4{ }^{\circ} \mathrm{C}$. However, samples stored at $22{ }^{\circ} \mathrm{C}$ decreased rapidly after $4 \mathrm{~d}$ of storage as shown in Fig. 1D. Both total antioxidant activities and vitamin $\mathrm{C}$ content showed similar trends, with the content remaining constant at $4{ }^{\circ} \mathrm{C}$ and decreasing after $6 \mathrm{~d}$, whereas, the total antioxidant activities and vitamin $\mathrm{C}$ stored at $22{ }^{\circ} \mathrm{C}$ decreased immediately after $2 \mathrm{~d}$ as shown in Fig. 2C and $\mathrm{D}$. The concentration of variables held at $4{ }^{\circ} \mathrm{C}$ was higher than at $22^{\circ} \mathrm{C}$, especially before $6 \mathrm{~d}$.

Using results from storage temperatures and storage duration, $\mathrm{Mg}$
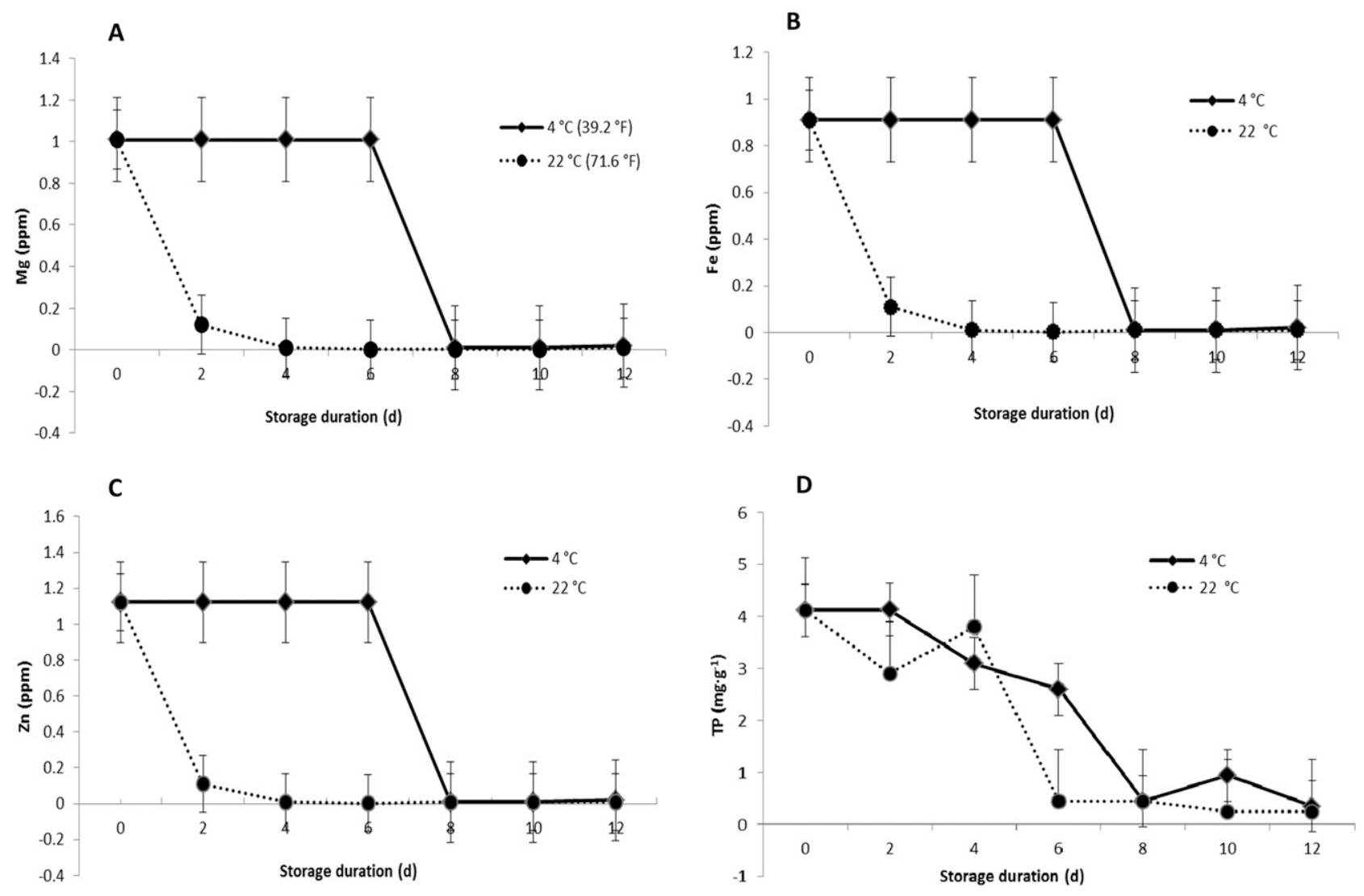

Fig. 1. Influence of storage at different temperatures $\left(4\right.$ and $\left.22{ }^{\circ} \mathrm{C}\right)$ for different set durations $(2,4,6,8,10$, and $12 \mathrm{~d})$ on variables (mean $\pm \mathrm{SE})$ : (A) magnesium $(\mathrm{Mg}),(\mathrm{B})$ iron $(\mathrm{Fe}),(\mathrm{C})$ zinc $(\mathrm{Zn})$, and $(\mathrm{D})$ total phenols $(\mathrm{TP})$ of baby spinach leaves; $1 \mathrm{ppm}=1 \mathrm{mg} \cdot \mathrm{kg}^{-1}$. 

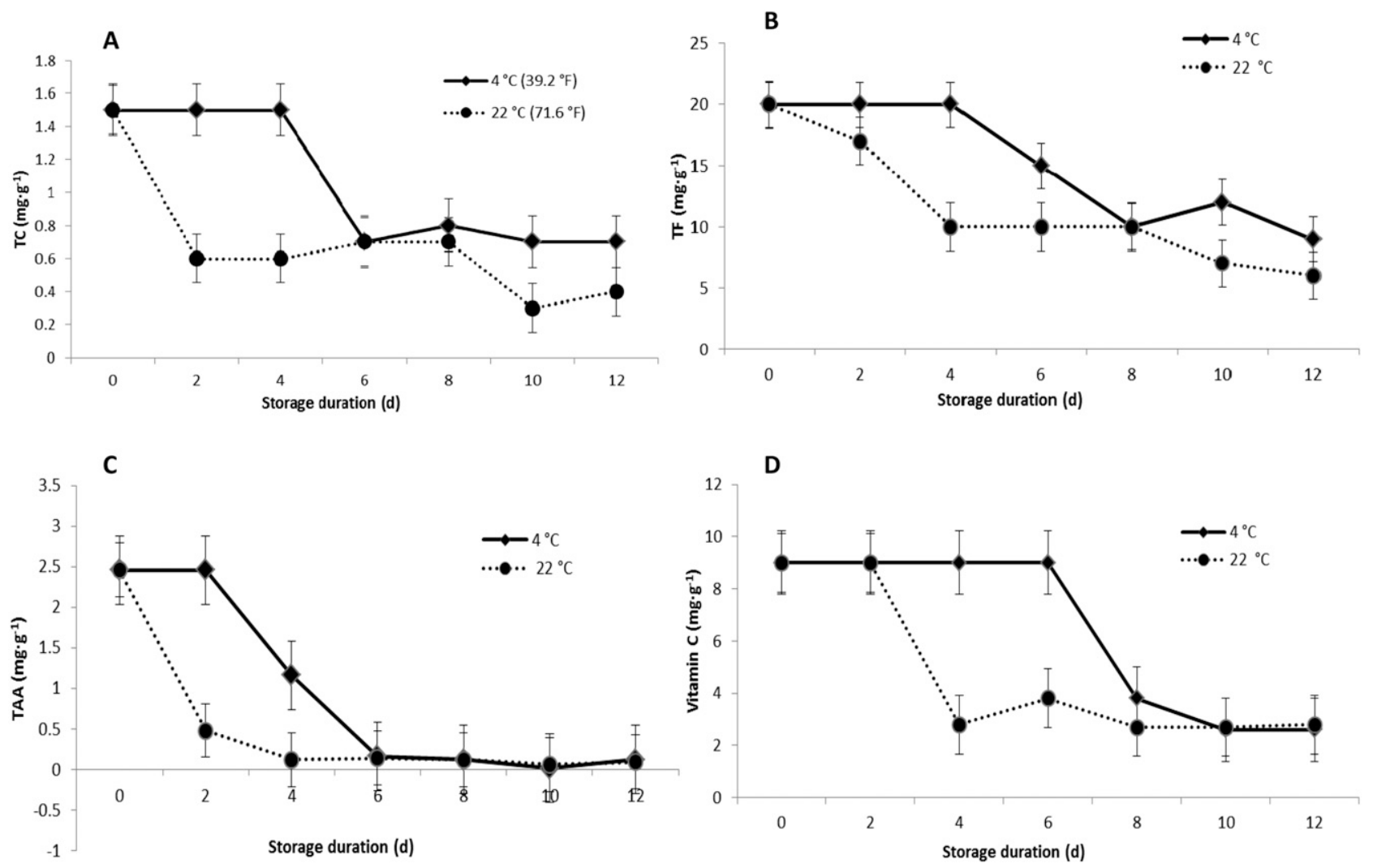

Fig. 2. Influence of storage at different temperatures $\left(4\right.$ and $\left.22^{\circ} \mathrm{C}\right)$ for different set durations $(2,4,6,8,10$, and $12 \mathrm{~d})$ on variables (mean $\pm \mathrm{SE})$ : (A) total carotenoids (TC), (B) total flavonoids (TF), (C) total antioxidant activity (TAA), and (D) vitamin $\mathrm{C}$ of baby spinach leaves; $1 \mathrm{mg} \cdot \mathrm{g}^{-1}=0.1 \%$.

content was strongly correlated with both the $\mathrm{Fe}$ and $\mathrm{Zn}$ content $(R=$ 0.99 ) as shown in Table 2. The correlation for total phenolics and total carotenoids was 0.58 , whereas vitamin $\mathrm{C}$ and total flavonoids content were strongly correlated $(R=$ 0.91 ) (Table 2).

\section{Discussion}

Rickman et al. (2007) reported that minerals are unaffected by storage treatments ranging from -20 to $20^{\circ} \mathrm{C}$. Our results demonstrated that $\mathrm{Mg}, \mathrm{Fe}$, and $\mathrm{Zn}$ were well retained in the spinach leaves that were stored at $4^{\circ} \mathrm{C}$ than those stored at $22{ }^{\circ} \mathrm{C}$. In contrast, Bouzari et al. (2015) and Belloso and Barriobero (2001) reported no significant differences in mineral content between frozen and fresh samples at -27.5 and $2{ }^{\circ} \mathrm{C}$ for 0 , 3 , and $10 \mathrm{~d}$.

Data obtained also demonstrated that cold storage at 4 and $22{ }^{\circ} \mathrm{C}$ had some effects on carotenoid concentration. During storage at $4{ }^{\circ} \mathrm{C}$, the total carotenoid content remained constant until day 4 , and thereafter dropped. Similar findings

Table 2. Correlations among the measured parameters of baby spinach stored at two different temperatures $\left[4\right.$ and $22^{\circ} \mathrm{C}\left(39.2\right.$ and $\left.\left.71.6{ }^{\circ} \mathrm{F}\right)\right]$ for different storage duration $(2,4,6,8,10$, and $12 \mathrm{~d})$.

\begin{tabular}{lllllll}
\hline $\begin{array}{l}\text { Measured } \\
\text { parameters }^{\mathbf{z}}\end{array}$ & $\mathbf{M g}$ & $\mathrm{Fe}$ & $\mathbf{Z n}$ & $\mathrm{TP}$ & TC & TF \\
$\mathrm{Mg}$ & 1 & & & & \\
$\mathrm{Fe}$ & $0.99^{*}$ & 1 & & & \\
$\mathrm{Zn}$ & $0.99^{*}$ & $0.99^{*}$ & 1 & & \\
$\mathrm{TP}$ & $0.67^{*}$ & $0.67^{*}$ & $0.66^{*}$ & 1 & & \\
$\mathrm{TC}$ & $0.76^{*}$ & $0.76^{*}$ & $0.76^{*}$ & $0.59^{*}$ & 1 & \\
$\mathrm{TF}$ & $0.81^{*}$ & $0.81^{*}$ & $0.81^{*}$ & $0.78^{*}$ & $0.83^{*}$ & 1 \\
\hline
\end{tabular}

${ }^{2} \mathrm{Mg}=$ magnesium; $\mathrm{Fe}=$ iron; $\mathrm{Zn}=$ zinc $; \mathrm{TP}=$ total polyphenols; $\mathrm{TC}=$ total carotenoids; $\mathrm{TF}=$ total flavonoids. *Significant at $P \leq 0.05$.

were reported by Kopas-Lane and Warthesen (1995) who observed a decrease in carotenoids, all-trans and 13 -cis $\beta$-carotene, stored at $4{ }^{\circ} \mathrm{C}$ just after $4 \mathrm{~d}$. Similarly, Pandrangi and Laborde (2004) reported that after 8 and $4 \mathrm{~d}$ of storage at 4 and $20^{\circ} \mathrm{C}$, respectively, total carotenoids maintained were $54 \%$ and $44 \%$ of initial detected levels. This implies that the carotenoid content in spinach samples generally decreases as storage time increased and degrades more rapidly at high temperature. Nevertheless, our study's findings are in contradiction with those reported by Bergquist et al. (2006), who described an increase of carotenoid content during storage. The carotenoid level increase was more noticeable at $10{ }^{\circ} \mathrm{C}$ than at $2{ }^{\circ} \mathrm{C}$ (Bergquist et al., 2006), presumably due to lowstorage temperatures ranging from 2 to $10{ }^{\circ} \mathrm{C}$. However, since carotenoids remain quite stable or increase during storage, the ascorbic acids content may play a predominant role in the nutritional quality of baby spinach during storage (Bergquist et al., 2006). 
The results of this study additionally showed that phenolics were well retained in spinach samples placed in both 4 and $22{ }^{\circ} \mathrm{C}$ until the 5 th $\mathrm{d}$ of storage, but subsequently dropped at $4{ }^{\circ} \mathrm{C}$ from the value of 3.1 to 2.6 , while at $22{ }^{\circ} \mathrm{C}$ dropped from a value 3.8 down to 0.45 . Our data revealed no significant differences between samples stored at 4 and $22^{\circ} \mathrm{C}$ with respect to phenolic content. Bouzari et al. (2015) reported that spinach showed no significant differences between fresh and frozen produce stored at 2 and $-27.5{ }^{\circ} \mathrm{C}$, respectively. It has been suggested that degradation of total phenolic content during storage may possibly be attributed to sensitiveness toward oxidation (Rickman et al., 2007). Leja et al. (2001) reported very good stability of total phenols in broccoli (Brassica oleracea var. italica) during a postharvest storage period of $\approx 7 \mathrm{~d}$ at $5{ }^{\circ} \mathrm{C}$, while broccoli samples stored at $20{ }^{\circ} \mathrm{C}$ showed an increase in phenolic content. According to Podsędek (2007), such findings might be strongly influenced by weight loss that led to an increase of phenolic content in the cells.

The level of antioxidant activity decreased significantly and rapidly at a storage temperature of $22{ }^{\circ} \mathrm{C}$, though samples stored at $4{ }^{\circ} \mathrm{C}$ took $2 \mathrm{~d}$ before declining. Bottino et al. (2009) reported that the antioxidant capacity of spinach as a result of the high quantities of vitamin $\mathrm{C}$ and phenolic compounds. This notion has been supported by Kurilich et al. (2002) who reported that the hydrophilic extracts were responsible for $80 \%$ to $95 \%$ of the total antioxidant capacity.

Temperature and storage duration have been reported to have undesired impacts on the content of vitamin $\mathrm{C}$ in vegetables (Lee and Kader, 2000). Studies have shown a rapid decrease in concentration of vitamin $\mathrm{C}$ during postharvest storage in samples stored at $10^{\circ} \mathrm{C}$ (Bergquist et al., 2006; Favell, 1998; Gil et al., 1999; Hodges and Forney, 2003). However, in this study, the concentration of vitamin $\mathrm{C}$ was not found to decrease across the storage periods in the first $6 \mathrm{~d}$. Vitamin $\mathrm{C}$ concentrations in the spinach stored at $4{ }^{\circ} \mathrm{C}$ remained quite constant and therefore decreased slowly. This was probably because at low temperatures the degradation rate of vitamin $\mathrm{C}$ is very slow compared with high temperatures. Furthermore, these findings concur with the study of Bergquist et al. (2007) who reported that the vitamin $\mathrm{C}$ concentration did not always decline throughout the storage period on samples stored at $2{ }^{\circ} \mathrm{C}$. In baby spinach stored at $22^{\circ} \mathrm{C}$, there was a decrease in the level of vitamin $\mathrm{C}$ within $3 \mathrm{~d}$. Similar findings were reported by Diplock et al. (1998), who reported that more than $90 \%$ of the vitamin $\mathrm{C}$ is lost within $3 \mathrm{~d}$ of storage at ambient temperature. This study also showed strong correlation in vitamin $\mathrm{C}$ and total flavonoids content in baby spinach, as reported by Koh et al. (2012) in other spinach varieties.

\section{Conclusion}

In conclusion, storage period and temperature were found to have different effects on $\mathrm{Mg}, \mathrm{Fe}, \mathrm{Zn}$, phenolics, antioxidant activity, flavonoids, carotenoids, and vitamin C. Baby spinach leaves stored at $4{ }^{\circ} \mathrm{C}$ maintained good quality for 4 to $6 \mathrm{~d}$ as compared with those stored at $22{ }^{\circ} \mathrm{C}$ like in a retail store. This gives a valuable indication to the conditions most favorable and optimum in adjusting current postharvest practices. Current methods may be improved by altering conditions best suitable for preserving baby spinach quality with prolonged shelf life. Baby spinach is a highly perishable that requires proper handling and storage to preserve their best quality from postharvest handling practices without losing essential nutrients reputed to the crop. Therefore, the current study will provide guidance to the farmers on what best practices should be employed to maintained good quality baby spinach after harvest.

\section{Literature cited}

Ahvenainen, R. 1996. New approaches in improving the shelf life of minimally processed fruit and vegetables. Trends Food Sci. Technol. 7:179-187.

Awika, J.M. and L.W. Rooney. 2004. Sorghum photochemical and their stability in sunflower oil and emulsion. Food Chem. 64:323-329.

Ayala-Zavala, J.F., S.Y. Wang, C.Y. Wang, and G.A. González-Aguilar. 2004. Effect of storage temperatures on antioxidant capacity and aroma compounds in strawberry fruit. Swiss Soc. Food Sci. Technol. 37:687-695.

Belloso, M.O. and L.E. Barriobero. 2001. Proximate composition, minerals and vitamins in selected canned vegetables. Eur. Food Res. Technol. 212:182-187.

Bergquist, S.A.M., U.E. Gertsson, P. Knuthsen, and M.E. Olsson. 2005. Flavonoids in baby spinach (Spinacia oleracea $\mathrm{L}$.): Changes during plant growth and storage. J. Agr. Food Chem. 53:94599464.

Bergquist, S.A.M., U.E. Gertsson, and M.E. Olsson. 2006. Influence growth stage and postharvest storage on ascorbic acid and carotenoid content and visual quality of baby spinach (Spinacia oleracea L.). J. Sci. Food Agr. 86:346-355.

Bergquist, S.A.M., U.E. Gertsson, L.Y.G. Nordmark, and M.E. Olsson. 2007. Effects of shade nettings, sowing time and storage on baby spinach flavonoids. J. Sci. Food Agr. 87:2464-2471.

Bottino, A., E. Degl'Innocenti, L. Guidi, G. Graziani, and V. Fogliano. 2009. Bioactive compounds during storage of fresh-cut spinach: The role of endogenous ascorbic acid in the improvement of product quality. J. Agr. Food Chem. 57:2925-2931.

Bouzari, A., D. Holstege, and D. Barret. 2015. Mineral, fiber, and total phenolic retention in eight fruits and vegetables: A comparison of refrigerated and frozen storage. J. Agr. Food Chem. 63:951-956.

Diplock, A.T., J.L. Charleux, G. CrozierWilli, F.J. Kok, C. Rice-Evans, M. Roberfroid, W. Stahl, and J. Vina-Ribes. 1998. Functional food science and defence against reactive oxygen species. Brit. J. Nutr. 80:77-112.

Favell, D.J. 1998. A comparison of the vitamin $\mathrm{C}$ content of fresh and frozen vegetables. J. Agr. Food Chem. 62:59-64.

Gil, M.I., F. Ferreres, and F.A. TomásBarberan. 1999. Effect of postharvest storage and processing on the antioxidant constituents (flavonoids and vitamin C) of fresh-cut spinach. J. Agr. Food Chem. 47:2213-2217.

Hanlon, E.A., J.G. Gonzalez, and J.M. Bartos. 1994. IFAS extension soil testing laboratory chemical procedure and training manual. Univ. Florida Coop. Ext. Serv. Circ. 812 .

Hodges, D.M. and C.F. Forney. 2003. Postharvest ascorbate metabolism in two cultivars of spinach differing in their senescence rates. J. Amer. Soc. Hort. Sci. 128:930-935.

Hulshof, P.J.M., C. Xu, P. van de Bovenkamp, P. Muhilal, and C.E. West. 
1997. Application of a validated method for the determination of provitamin A carotenoids in Indonesian foods of different maturity and origin. J. Agr. Food Chem. 45:1174-1179.

Izumi, H., T. Nonaka, and T. Muraoka. 1997. Physiology and quality of fresh-cut spinach stored in low $\mathrm{O}_{2}$ controlled atmospheres at various temperatures, $\mathrm{p}$. 130-133. In: J.R. Gorny (ed.). 1997 Proc. Vol. 5: Fresh-cut fruits and vegetables and MAP. Univ. California, Davis, CA.

Kader, A.A. and R.S. Rolle. 2004. The role of post-harvest management in assuring the quality and safety of horticultural produce. FAO Agr. Serv. Bul. 152. 9 Oct. 2014. <http://www.fao.org/3/ a-y5431e.pdf/>.

Kidmose, U., P. Knuthsen, M. Edelenbos, U. Justesen, and E. Hegelund. 2001. Carotenoids and flavonoids in originally grown spinach (Spinacia oleraceae L.) genotypes after deep frozen storage. J. Sci. Food Agr. 81:918-923.

Koh, E., S. Charoenprasert, and A.E. Mitchell. 2012. Effect of organic and conventional cropping systems on ascorbic acid, vitamin $\mathrm{C}$, flavonoids, nitrate, and oxalate in 27 varieties of spinach (Spinacia oleracea L.). J. Agr. Food Chem. 60:3144-3150.

Kopas-Lane, L.M. and J.J. Warthesen. 1995. Carotenoid photostability in raw spinach and carrots during cold storage. J. Sci. Food Agr. 60:773-776.

Kurilich, A.C., E.H. Jeffery, J.A. Juvik, M.A. Wallig, and B.P. Klein. 2002. Antioxidant capacity of different broccoli (Brassica oleracea) genotypes using the oxygen radical absorbance capacity (ORAC). J. Agr. Food Chem. 50:5053-5057.

Lee, S.K. and A.A. Kader. 2000. Preharvest and postharvest factors influencing vitamin $\mathrm{C}$ content of horticultural crops. Postharvest Biol. Technol. 20:207220.

Leja, M., A. Mareczek, A. Starzyńska, and S. Rożek. 2001. Antioxidant ability of broccoli flower buds during short term storage. Food Chem. 72:219-222.

Maughan, P.J., A. Bonifacio, E.N. Jellen, M.R. Stevens, C.E. Coleman, M. Ricks, S.L. Mason, D.E. Jarvis, B.W. Gardunia, and D.J. Fairbanks. 2004. A genetic linkage map of quinoa (Cheponodium quinoa) based on AFLP, RAPD, and SSR markers. Theor. Appl. Genet. 10:11881195.

Moretti, C.L. 2007. Manual de processamento minimo de frutas e hortalicas. lst ed. Embrapa Hortalicas, Rio de Janeiro, Brasil.

Muller, H. 1997. Determination of the carotenoid content in selected vegetables and fruit by HPLC and photodiode array detection. Z. Lebensm. Unters. Forsch. 204:88-94.

Muramoto, J. 1999. Comparison of nitrate content in leafy vegetables from organic and conventional farms in California. 18 Sept. 2015 . <http://www. agroecology.org/documents/Joji/ leafnitrate.pdf $>$.
Nemadodzi, L.E. 2015. Growth and development of baby spinach (Spinacia oleraceae L.) in response to mineral nutrition. Univ. South Africa, Johannesburg, MSc Diss.

Pandrangi, S. and L.F. Laborde. 2004. Retention of folate, carotenoids, and other quality characteristics in commercially packaged fresh spinach. J. Food. Sci. 69(9):702-707.

Podsędek, A. 2007. Natural antioxidants and antioxidant capacity of Brassica vegetables: A review. Swiss Soc. Food Sci. Technol. 40:1-11.

Rickman, J.C., C.M. Bruhn, and D.M. Barrett. 2007. Nutritional comparison of fresh, frozen, and canned fruits and vegetables-II. Vitamin A and carotenoids, vitamin E, minerals and fiber. J. Sci. Food Agr. 87:1185-1196.

Singleton, U.L. and J. Rossi. 1965. Colorimetry of total phenolics with phosphomolybdic-phosphotungstic acid reagent. Amer. J. Enol. Viticult. 6:144-158.

Van der Walt, A.M., D.T. Loots, M.I.M. Ibrahim, and C.C. Bezuidenhout. 2009. Minerals, trace elements and antioxidant phytochemicals in wild African dark-green leafy vegetables (morogo). S. Afr. J. Sci. 105:11-12.

Waterman, P.G. and S. Mole. 1994. Analysis of plant metabolites. Alden Press, Oxford, United Kingdom.

Yoo, K.M., C.H. Lee, H. Lee, B. Moon, and C.Y. Lee. 2008. Relative antioxidant and cytoprotective activities of common herbs. Food Chem. 106:92-96. 